\title{
Public Relations \\ Rhetoric: Criticism, \\ Dialogue, and the \\ Long Now
}

Management Communication Quarterly

25(3) 550-559

(C) The Author(s) 2011

Reprints and permission: http://www. sagepub.com/journalsPermissions.nav

DOI: $10.1177 / 08933$ |89||40988|

http://mcq.sagepub.com

@SAGE

\section{Michael L. Kent'}

\begin{abstract}
This essay provides a response to the articles in this special issue by introducing the concepts of dialogue, groupthink, and long-term thinking. The philosophy of the Long Now Foundation (an organization devoted to sustainable development and long-term planning) is used as a frame for the essay because of its close fit with rhetoric and dialogue. The essay examines the contributions to the special issue and identifies similarities of thought and argument.
\end{abstract}

\section{Keywords}

rhetoric, dialogue, groupthink, Long Now, relationship, responsibility, patience, myth, narrative

A useful response to other articles in this issue draws connections among ideas and leads readers to think about topics that might not have been obvious as they read. This response points to the common ground shared by authors in this special issue and introduces several rhetorical concepts to further explain how rhetoric and public relations come together to build civil society.

One of the obvious commonalities is the role that critique or criticism plays. Coombs and Holladay conduct a critique of self-regulatory discourse

\footnotetext{
'University of Oklahoma, Norman, OK, USA
}

\section{Corresponding Author:}

Michael L. Kent, University of Oklahoma, Gaylord College of Journalism and Mass

Communication, 395 W. Lindsey, Norman, OK 73019-4201, USA

Email: MKent@OU.edu 
examining two case studies, The Entertainment Software Rating Board and direct to consumer advertising. Taylor examines the concept of social capital and conducts a critique of Aqaba Jordan and its use of dialogue. Ihlen (2011) argues for "analysis of the archetypal rhetorical strategies" (p. 456) and explores Bitzer's (1968) notion of the rhetorical situation. Frandsen and Johansen explore the rhetoric produced by car producers in Denmark. Waymer and Boyd call for more critical reflection by scholars of organizational rhetoric looking at power, race, class, gender, and the adversarial system, while Heath unpacks an assortment of rhetorical principles that help explain how organizations act in a fully functioning society.

What we see in the essays is a resurgence of the role of rhetoric in social science and public relations. Each of the essays draws heavily on critique and the concept of "propaganda criticism" (Sproule, 1987). As Sproule (1987) explained more than two decades ago,

The story of propaganda analysis offers an exemplar of how a paradigm arises in response to social needs for knowledge, and how a paradigm declines and is displaced when changing conceptions of what constitutes knowledge are reinforced by the interests of powerful social institutions. (p. 60)

The authors in this special issue demonstrate the viability of a criticalrhetorical approach to public relations and its ability to improve society and professional practice. The assumption in many of these essays is that communication is a complex process that is influenced and even corrupted by power, organizational interests, language, and human interaction. To enact a fully functioning society requires an understanding of many rhetorical principles.

In the spirit of classical rhetoric, and in keeping with the relational turn that the field of public relations has taken, calls for increased rhetoric always beg the question of how. Saying that the rhetorical situation is useful for understanding organizational rhetoric (Ihlen) or calling on organizations to examine hegemonic principles more reflectively (Waymer \& Boyd) leads to the question of how.

As Baskerville (1977) once lamented, "Must we all be rhetorical critics?" How do organizations decide what to respond to? How do organizations step outside of long-established hegemonic organizational structures and make decisions about how to proceed? This essay draws attention to how the rhetorical critiques in this special issue might actually be enacted. The rhetorical and professional communication concepts of long-term thinking and dialogue are 
used to try and answer the question of how to enact rhetoric on behalf of a fully functioning society.

\section{Long-Term Thinking}

Much of public relations is characterized by thinking in the present, whereas most publicly held organizations think little beyond the next quarter's profits. One solution to the myopic focus of organizations on short-term profits and next-quarter thinking is for public relations professionals to encourage organizations to work toward long-term goals. Long-term thinking and planning necessitate an entirely different organizational paradigm. Rather than our focus being on resolving crises after the fact, or criticizing unethical organizations, a substantial portion of the time of communication professionals should be devoted to avoiding crisis and changing the rhetorical milieu of organizations and society to solve problems constructively rather than mitigate their impact.

When people and organizations lift their eyes to the horizon they realize that getting there requires some friends with whom to journey beyond what they immediately see. Although many communication professionals speak of our obligation to "counsel" clients, counseling is often reified as "telling someone what to do to stay out of trouble." A long-term approach to strategic planning and stakeholder communication might draw on the idea of long-term thinking such as is proposed by "the Long Now," the theme advanced by an organization dedicated to thinking hundreds of quarters ahead, not just one or two.

A Long Now approach sees counseling as an activity designed to make someone better (or "well" in the clinical sense). Counseling is a moral responsibility, not a legal one, and the Long Now approach serves as a model.

"The Long Now Foundation was established in 01996 [the extra decimal represents the long-term focus of the foundation] to ... become the seed of a very long-term cultural institution" (longnow.org/about). As founding board member Stewart Brand explains,

Civilization is revving itself into a pathologically short attention span. The trend might be coming from the acceleration of technology, the shorthorizon perspective of market-driven economics, the next-election perspective of democracies, or the distractions of personal multi-tasking. All are on the increase. Some sort of balancing corrective to the shortsightedness is needed - some mechanism or myth which encourages the long view and the taking of long-term responsibility, where "long-term" is measured at least in centuries. (longnow.org/about) 
According to the Long Now Foundation, "Guidelines for a long-lived, long-valuable institution" include "Serve the long view, Foster responsibility, Reward patience, Mind mythic depth, Ally with competition, Take no sides, and Leverage longevity" (www.longnow.org/about).

Rhetoricians have had a sense of communication serving future-oriented goals for thousands of years. Of the three types of rhetoric talked about by Aristotle (1991) 2,500 years ago (forensic, deliberative, and epideictic), deliberative rhetoric looks to the future to construct a better tomorrow, given the conditions and challenges at hand. The ancient world understood that not everyone acts in the best interest of society. Individuals are often guided by self-interest and held in check by social convention and the will of others (cf. Heath, [this issue]). Thus, thoughtful professionals coming together in the light of day have a role to play in shaping the future. Coombs and Holladay (2011) argue as much in their essay noting

There is a lack of self-reflection on the utilization of self-regulatory discourse and an understanding of how to evaluate its effects on society. ... We can ask two questions to uncover the true nature of self-regulation: 1. What threat does the issue pose to constituents? 2. Does the self-regulation empower constituents to redress the threat/ protect themselves? (p. 499)

The critical move to evaluate the plans and messages of organizations and professionals is an indispensable role that public relations professionals can play as information providers to society.

\section{The Long Now as a Framework for Public Relations}

The idea of a Long Now focus in public relations is to bring back notions of relationship and obligation. True relationships are two-way streets not simply built on a "two-way flow of information" and "rights" but, more importantly, built on obligations, as the communitarians suggest (cf. Etzioni, 1993).

External organizational rhetoric is more than messages delivered by spokespeople. Organizational rhetoric includes images and opinions created by political punditry, news reporting, and editorializing in the mass media. Organizational rhetoric also includes the content of classroom lectures, politicians' endorsements, and criticism of organizations and their leaders, chatter in the blogosphere, twittering about local and national events, and talk by 
people in their social and civic organizations - what Taylor called the core of civil society. In short, to speak of the Long Now and how organizations might use rhetoric to build civil society and a fully functioning society means focusing on relationships and messages at many levels.

A second commonality of thought in the articles in the special issue is the principle of dialogue. Taylor refers to dialogue in her analysis of ASEZA and their work with neighborhood groups. Ihlen (2011) notes, "Open and responsible dialogue is suggested as the ethical ideal" (p. 457). Waymer and Boyd discuss dialogue throughout their essay. Coombs and Holliday conduct analyses of organizational dialogue. Heath talks about dialogue as part of the process of enlightened choice and cooperative competition.

\section{Dialogue as a Rhetorical Tool}

As authors in this special issue have pointed out, rhetorical critique is necessary to make organizations more sensitive societal members; however, ultimately, critical examination requires an organizational climate and structure that values questioning decisions and making long-term thoughtful decisions rather than mere crisis responses. Communication professionals need to begin the hard task of shaping the organizational climate to suit a Long Now perspective. Public relations professionals have an important role to play as modern propaganda critics, enacting and employing rhetorical principles and long-term dialogic approaches, all of which are part of the mix.

Another component of bringing rhetoric into play in constructing a fully functioning society is for organizations to realize that their decisions need to be better-not financially better but rhetorically better. The best decisions are informed by long-term planning (serve the long view, reward patience, ally with competition, leverage longevity) and a decision-making approach dedicated to minimizing errors and maximizing the organization-social relationship.

\section{Decision Making as a Component of Dialogue}

At the heart of Long Now thinking is planning far into the future-making long-term decisions. Decision making that is rushed, palliative, and focused solely on alleviating today's problem is not a Long Now approach. Good decisions take time, good decisions often create conflict and dissensus as often as consensus, and good decisions require bringing in outside experts when necessary to inform decision making.

Many have written about decision making; indeed, the literature on decision making in economics, psychology, and political science is vast. Many 
issues including the gamblers' fallacy, base rate errors, subjective expected utility (SEU), luck, fair division, and other heuristics need to be explored by organizations that are committed to making sound decisions. One area of decision-making scholarship that has stood the test of time is groupthink.

The theory of groupthink was developed in the 1970s by Irving Janis (1982) to help explain why small groups of experts and professionals often make bad decisions. Groupthink has been applied to big decisions like Kennedy's "Bay of Pigs" fiasco and the Nazi regime and dozens of other less important but still consequential decisions that also failed. Groupthink explains why highly cohesive groups - whether experts or novices - make bad decisions.

The essence of groupthink has to do with the fact that highly cohesive groups and groups with high power distance (Hofstede, 1997) are often closedminded and fail to ask questions or explore alternatives issues (problems dialogue and long-term thinking avoid). Avoiding groupthink is a rhetorical (dialectical) process in that it assumes that no one can know everything and that questioning ideas leads to better ideas and decisions.

Types of groupthink include overestimations by a group of its power and morality, closed-mindedness, and pressures toward uniformity (Janis, 1982, p. 174). Conditions that promote groupthink include insulation of the policymaking group, a lack of a tradition of impartial leadership, and a lack of norms requiring methodical procedures for dealing with decision-making tasks (pp. 174-175). Symptoms of defective decision making include an incomplete survey of alternatives and objectives, a failure to examine risks of preferred choice and reappraise initially rejected alternatives, poor research, a selective bias in processing information at hand, and a failure to work out contingency plans (p. 174).

Ultimately, good decisions are made when organizations are open to feedback, people feel confident and safe in expressing their ideas (they should be encouraged to provide input), and decisions are made with the aim of making the best (long-term) decision and not just the most expedient. Good decisions are rhetorical, dialogic, and informed by research.

External organizational rhetoric should also serve the more lofty goals imposed by dialogue, decision-making structures, long-term thinking, and responsibility (obligation) to others. Organizational communication professionals need to begin to work on changing the climate and transforming organizations into places of trust and responsibility. We should not accept that organizations have no social obligations but to themselves. "Enlightened self-interest" (discussed by Heath) is not "self-centeredness." Enlightened self-interest might see an oil company supporting restrictions on offshore 
drilling not because it gives them a competitive advantage but because it levels the playing field for everyone and is in the best interest of society. We see little "enlightenment" or long-term thinking in the decisions of many corporate executives who argue that corporations have no obligation except to make money for shareholders. Concepts like rhetoric and self-interest are considerably more complex, as Heath argues here and elsewhere (cf. Heath et al., 2006).

\section{Integrating Rhetoric Into a Fully Functioning Society}

When looking at the articles in this special issue, the authors see distinct types of rhetoric, mass or public rhetoric, and group/interpersonal rhetoric. Professional communicators often speak of and study the rhetoric of influential individuals and major corporations as a means of understanding effective communication (cf. crisis, issues management, political, Legal Public Relations LPR). However, professional communicators also need to focus on the internal rhetoric of decision makers and leaders the way that organizational communication scholars do.

Frandsen and Johansen, for example, explain how many of the Danish automakers they studied have created environmental "awards" that they give to themselves. These monologues only point to the inward focus common in many large organizations. Essentially, they have institutionalized groupthink (Janis, 1982) and an incomplete survey of alternatives and objectives. Similarly, as Ihlen (2011) suggested, modern rhetors "must deal with the challenges presented by an increasingly fragmented, rapidly changing, and complex world" (p. 466) —an external focus ignoring internal issues.

By relying on internal self-praise in place of external scrutiny, the automakers avoid actually having to come to terms with the problem of pollution. Indeed, the focus of Frandsen and Johansen's essay (and Ihlen's) is to critique the external rhetoric of specific organizations. Although we can never be sure of what factors go into the decisions that produce rhetoric, all rhetoric is informed by three things: speaking (or communication), thinking, and acting. "We speak the way we speak because we are the way we are," as Dominick Larusso said in a lecture at the University of Oregon in 1991. As agenda-setting theory points out (Kent, 2011), being exposed to ideas is a precursor to action. Until we know of an idea, or conceive it, we cannot act on it. Thus, communication influences thought and action, just as action influences communication and thought. Dialogue, then, not only forces participants to hear multiple and competing viewpoints but also forces them to 
articulate their own views (speaking and thinking). More diverse and wellinformed ideas lead to better decisions, better actions, and better communities.

Rhetoric is a complicated process as the authors in this special issue point out. Boyd and Waymer (2011) argue, "Scholars of organizational rhetoric need to take a skeptical stance that identifies the multiple interests involved and unpacks hidden ideographs and assumptions" (p. 475; mind mythic depth), whereas Heath (2011) writes, under social constructionism, "language is not a tool, but a way of understanding the dynamics of discourse creating shared and competing world-views that shed light onto the vicissitudes of coordinating social action" (p. 416).

In spite of their "social construction," in practice, many organizations act as if they are distinct from citizens and society. The desire by organizations to be able to speak as citizens and yet remain distinct from the consequences of their speech and symbolic actions (cf. Burke, 1966) because they speak as corporate entities (cf. Sproule, 1988) is an example of a dysfunctional corporate worldview. The view of largely static organizations ruled by their cybernetic adjustment to their environments is further reinforced by Heath's notion of "corporate dialectic" in which organizations are called on to do the right thing through cooperative competition-because they are forced to through their environments, rather than because they choose to do the right thing.

We cannot expect individuals and corporate entities simply to do the right thing without a diverse network of relationships with external stakeholders to which individuals and organizations feel tied. The Long Now, including dialogue, as a tool in the decision-making process naturally leads to better decisions and more moral and ethical decisions. More importantly, the view from the Long Now of the "good corporate citizen" that thinks in terms of satisfying networks of stakeholders - some of whom have nothing to offer the organization today - will make better, more ethical, civic choices and "foster responsibility."

\section{Conclusion}

Rhetoric is often seen as mere persuasion, as a sword wielded to vanquish one's foes rather than as a tool to mete out justice. The Long Now approach and dialogue are not quick fix approaches. Taylor, for example, talks about Boulding's (1977) idea of "images" to explain how both individual and public perceptions come into play. Issues like fostering responsibility, engaging in dialogue, and encouraging trust are part of the Long Now process. 
Abundant interpersonal and psychological research suggests that our decisions are influenced by the actions and beliefs of others. Rhetoric argues that our beliefs and society are socially constructed just as social science argues that people do not blindly act on their beliefs. We act because of what we think other individuals and groups will think about us and because of external environmental cues (Kent, 2011). A fully functioning society, in general, and civil society, in particular, is built by people who educate themselves and fulfill their obligation to help others. Ethics, education, activism, and enlightened self-interest work together.

How to enact rhetoric across organizations is difficult. Creating fair, risk-free venues for dialogue and conversation takes years. Organizational members need to be trained; communication professionals need to work to create an effective climate. As Pearson (1989) pointed out, stakeholders themselves often need to be trained how to participate in decision-making processes. The hard part may not be dialogue but maintaining a long-term orientation and teaching stakeholders how to participate in the decision-making and policy process. Public relations and communication professionals have a big role to play.

Perhaps, because public relations professionals spend so much of our time dealing with new technology including software and hardware trends, changed cultural patterns, and demands by stakeholders for transparency and access, seeing our job as something besides damage control is difficult. The key to it all is marshalling rhetoric to do more than mere persuasion. Rhetoric educates, moves, and deliberates about the future. Rhetoric can only work if professionals use it to enact long-term principles in their organizations as the first step toward enacting a fully functioning society.

\section{Declaration of Conflicting Interests}

The author declared no potential conflicts of interest with respect to the research, authorship, and/or publication of this article.

\section{Funding}

The author received no financial support for the research, authorship, and/or publication of this article.

\section{References}

Aristotle (Kennedy, G. A., trans.) (1991). Aristotle on rhetoric: A theory of civic discourse. New York: Oxford University Press.

Baskerville, B. (1977). Must we all be "rhetorical critics?" Quarterly Journal of Speech, 62(2), 107-116.

Bitzer, L. F. (1968). The rhetorical situation. Philosophy \& Rhetoric 1(1), 1-14. 
Boulding, K. D. (1977). The image: Knowledge in life and society. Ann Arbor: University of Michigan Press.

Boyd, J., \& Waymer, D. (2011). Organizational Rhetoric: A Subject of Interest(s). Management Communication Quarterly, 25, 474-493.

Coombs, W. T., \& Holladay, S. J. (2011). Self-Regulatory Discourse: Corrective or Quiescent? Management Communication Quarterly, 25, 494-510.

Burke, K. (1966). Language as symbolic action. Berkeley: University of California Press.

Etzioni, A. (1993). The spirit of community: The reinvention of American society. New York, NY: Simon and Schuster.

Heath, R. L., Pearce, W. B., Shotter, J., Taylor, J. R., Kersten, A., Zorn, T., . . Deetz, S. (2006). The processes of dialogue: Participation and legitimation. Management Communication Quarterly, 19, 341-375.

Heath, R. L. (2011). External Organizational Rhetoric: Bridging Management and Sociopolitical Discourse. Management Communication Quarterly, 25, 415-435.

Hofstede, G. (1997). Cultures and organizations: Software of the mind. New York, NY: McGraw-Hill.

Ihlen, Ø. (2011). On Barnyard Scrambles: Toward a Rhetoric of Public Relations. Management Communication Quarterly, 25, 455-473.

Janis, I. L. (1982). Groupthink: Psychological studies of policy decisions and fiascoes. Boston, MA: Houghton Mifflin.

Kent, M. L. (2011). Public relations writing: A rhetorical approach. Boston, MA: Allyn \& Bacon.

Pearson, R. (1989). A theory of public relations ethics (Unpublished doctoral dissertation). Ohio University, Athens.

Sproule, J. M. (1987). Propaganda studies in American social science: The rise and fall of the critical paradigm. Quarterly Journal of Speech, 73(1), 60-78.

Sproule, J. M. (1988). The new managerial rhetoric and the old criticism. Quarterly Journal of Speech, 74, 468-486.

\section{Bio}

Michael L. Kent ( $\mathrm{PhD}$, Purdue University) is an associate professor of public relations at the University of Oklahoma, Norman. He conducts research and consults in the areas of new technology, dialogue, international public relations, and the media. 